\title{
Tańczące muzy. \\ Kino i korespondencja sztuk
}

Korespondencja sztuk należy do kluczowych zagadnień kina, na równi angażując inwencję praktyczną, jak i myśl teoretyczną. Nasuwa się pytanie: dlaczego w związku $\mathrm{z}$ kinem idea ta była zawsze - $\mathrm{i}$ jest nadal - taka ważna? Otóż z trzech zasadniczych powodów.

Po pierwsze, chodzi o akcelerację środków wyrazu w dziele filmowym, o jego wzmożoną ekspresję wynikającą z połączenia i specyficznego przymierza dziedzin, które zostały zaangażowane do współpracy i zjednoczone we wspólnym celu.

Po drugie, ze względu na ewidentny polimorfizm budowy utworu filmowego. Zjawisko korespondencji sztuk leży, by tak rzec, w naturze filmu jako specyficznej dziedziny sztuki: począwszy od różnorodnych w swym charakterze tworzyw (literatury, teatru, muzyki etc.), które zostały w nim użyte, a skończywszy na sposobach jednoczenia i organicznego związania z sobą różnorodnych elementów struktury danego dzieła.

Po trzecie wreszcie, ze względu na kulturowy kontekst i historyczne zaplecze samej idei, będącej od ponad stu lat niewyczerpanym źródłem energii sztuki filmowej w najróżniejszych jej dokonaniach i przejawach. To nie tylko kwestia teoretyczna. Rzecz ma również swoje bezpośrednie przełożenie na losy życiowe i wybory samych artystów. Od czasów Fregolego, Mélièsa i Chaplina, filmowiec chętnie przemienia się w człowieka-orkiestrę. W kinie polskim przychodzą natychmiast na myśl: Julian Antonisz, Andrzej Kondratiuk, Zbigniew Rybczyński, Lech Majewski.

Nie jest też dziełem przypadku, że wielu wybitnych twórców kina przyszło do filmu „z zewnątrz”, z innych dziedzin sztuki. Griffith, Murnau, Eisenstein i Bergman z teatru, Chaplin, Langdon i Keaton z music-hallu, Fritz Lang, Janusz Majewski i Robert Gliński z architektury, Mizoguchi, Kurosawa, Huston, Has, Wajda, Greenaway i Lynch z malarstwa, Konwicki i Robbe-Grillet z literatury. Méliès był wcześniej prestidigitatorem, Varda i Saura wziętymi fotografikami, Hitchcock po trosze wszystkim, a Fellini niezrównanym karykaturzystą (którym zresztą nigdy nie przestał być).

Nieważne skąd przychodzisz, ważne, co jako twórca z własnym bagażem doświadczeń umiesz i potrafisz wnieść do filmu. Nie sposób nie zauważyć, że idea correspondance des arts w odniesieniu do sztuki filmowej nie tylko zasila jej nieustanny rozwój, ale także niestrudzenie stymuluje twórczą przemianę, nadając jej wymiar w pewnej mierze uniwersalny. 
Aby dowiedzieć się i przekonać, jak bardzo uniwersalny charakter ma ta złożona kwestia, trzeba sięgnąć w przeszłość kultury znacznie głębiej, niż umożliwia to zachodni horyzont widoczny z greckiego Parnasu. W kulturach pierwotnych Dalekiego Wschodu (Indii, Japonii, Indonezji, Chin, Tybetu), a także Afryki i Europy, jedność sztuk była naturalną oczywistością, podobnie jak naturalna była ich koegzystencja i współpraca w ramach o wiele szerszego uniwersum. Za naturalną uchodziła także wielodziedzinowa biegłość wykonawcy-medium w zakresie wielu uprawianych przez niego sztuk oraz umiejętność łączenia i transponowania jednej w drugą. Taniec, śpiew, muzyka i poezja nie istniały jeszcze wtedy z osobna, nie zdążyły się wyodrębnić i wyspecjalizować. Nie strzegły też zazdrośnie własnych terytoriów i sztucznie wytyczonych granic. Uczestnicząc w odwiecznych rytuałach, dziedziny te łączyły się i stapiały w jedno, stając się częścią rytualnego przedstawienia i świętego obrzędu.

Tęsknota za tkwiącą w tym połączeniu magiczną mocą transformacji - zdolną przemieniać życie każdego z uczestników ceremonii i nadawać głęboki sens życiu danej zbiorowości - sprawiła, iż sztuka nowożytna zawsze pragnęła odnaleźć tamto zapomniane źródło. Wyjść poza ramy własnej specjalności, pokonać jej ograniczenia i sięgnąć po coś więcej. Dotyczy to nie tylko odległych czasów średniowiecza, renesansu czy baroku, lecz również epok bliższych współczesności.

Od oświecenia i romantyzmu począwszy, przez cały wiek XIX i XX artyści, wizjonerzy, filozofowie i uczeni, studiujący przeszłość sztuki, ulegali nieodpartej fascynacji ideą korespondencji sztuk, upatrując w niej szansę na odnowienie życia duchowego. Tak myśleli między innymi: Mozart, Lessing, Mickiewicz, Wagner, Nietzsche, Craig, Wyspiański, Witkacy, Eisenstein, Kurosawa, Fellini, Paradżanian, Grotowski. Spośród badaczy zaś: Bronisław Malinowski, Carl Gustav Jung, Rudolf Arnheim, Michaił Bachtin czy Joseph Rock.

Kino uchodzi w oczach wielu za urzeczone mirażem przyszłości dziecko nowoczesnej cywilizacji. Jednak, paradoksalnie, to właśnie film wielokrotnie powracał do pradawnego marzenia o sztuce sztuk. $\mathrm{O}$ arcysztuce, w której zacierają się granice poszczególnych dziedzin artystycznych. W owej syntezie sztuk, czy jak kto woli sztuce syntetycznej, nie ma już granic między poszczególnymi dziedzinami ani specjalizacji; zamiast tego dochodzi do głosu filmowa création collective, łącząca w całość wyższego rzędu najróżniejsze twórcze aspiracje i wszelkie niezbędne umiejętności, jakimi dysponuje ekipa filmowców.

Jako wytwór zaawansowanej technologii przełomu XIX i XX wieku, kinematografia wkrótce zaabsorbowała ideę korespondencji sztuk, zyskując status nowego środka przekazu zdolnego podbić masową widownię na całym świecie. Niezwykła popularność kina okazała się jego największym atutem. Dzięki temu już w pierwszym ćwierćwieczu swego istnienia stało się ono sztuką ludową, akceptowaną przez zwykłych ludzi i zrozumiałą dla milionów widzów. W odróżnie- 
niu od epok dawnych, indywidualizm artysty spotyka się tutaj z twórczym działaniem wysoko zorganizowanego zespołu i modelem kreacji zbiorowej.

Co jest pożyteczne dla danej dziedziny artystycznej, może okazać się szkodliwe dla filmu. U początków swego rozwoju sztuka filmowa, poszukując własnej tożsamości i zmierzając w swych dążeniach ku syntezie sztuk, wychodzi na spotkanie innym muzom po to, by zaczerpnąć dla siebie maksymalnie wiele z ich doświadczenia i osiągnięć. Dość szybko jednak okazuje się, że nie wszystko z danej sztuki służy filmowi, a sięgając do literatury, teatru czy malarstwa, należy przyswajać tylko rzeczy niektóre. Tak właśnie, metodą prób i błędów, rodziła się artystyczna samowiedza kina.

Warto tamten ważny historyczny moment zanotować. Kinematografia od swych najdawniejszych początków wspomagała się bowiem innymi sztukami. Pędząca przed siebie nowoczesność, odkąd po raz pierwszy już w XIX wieku spojrzała wstecz i odkryła na własny użytek przebogatą tradycję kultury artystycznej, czerpała z niej bezceremonialnie i pełnymi garściami. U boku filmowego Pegaza pojawiły się wkrótce: literatura, malarstwo, grafika, muzyka, balet, teatr, architektura. Ale także opera, operetka, wodewil, cyrk, music hall, taniec, pantomima, laterna magica, panoramy, żywe obrazy, komiks, fotografia, karykatura, kultura masowa. Dość szybko pierwsi filmowcy zorientowali się, że takie wspomaganie służy filmowi i przynosi mu wiele wymiernych korzyści. Z drugiej strony, rywalizacja różnych dyscyplin artystycznych może jednak szkodzić filmowi.

Z czasem okazało się, iż czerpać z osiągnięć innych sztuk to za mało. Trzeba jeszcze wiedzieć, jak to odpowiednio robić? W jaki sposób dana dziedzina może przydać się filmowi, nie narzucając mu niechcianego kanonu wypracowanych przez wieki zasad i dyktatu własnych warunków? Profilmowy sojusz sztuk powołał do istnienia szereg własnych sprawności i niezmiernie użytecznych kompetencji, takich jak: scenarzysta, reżyser, operator, scenograf, montażysta czy kompozytor muzyki filmowej, stając się w praktyce twórczej jedyną w swoim rodzaju symbiozą o wysokim stopniu złożoności.

Wraz $\mathrm{z}$ nią pojawiła się $\mathrm{w}$ miarę lat coraz bardziej rozwinięta kultura adaptacji. Nie tylko adaptacji literatury, rzecz jasna, lecz także szeroko pojętej adaptacji wielu innych sztuk. To dzięki niej już w epoce kina niemego powstały tysiące dzieł filmowych (Méliès, Zecca, Griffith, Starewicz, Chaplin, Murnau, Eisenstein, Gance, Dreyer i in.), w których zjednoczone muzy podają sobie ręce i tańczą razem z niebywałym wdziękiem.

Korespondencja sztuk nie jest żadną doktryną, lecz zjawiskiem żywym i nieustannie ewoluującym. Warto zauważyć, że w rozmaitych okresach i epokach idea ta ciągle powraca, to znów słabnie i zanika, mając charakter historycznie zmienny. W zależności od doraźnych preferencji estetycznych i związanych z nimi potrzeb, występuje ona w kulturze artystycznej danego miejsca i czasu w najróżniejszych 
swych odmianach. Raz bywa o niej głośno, kiedy indziej z kolei słabnie, zanika i ulega zmarginalizowaniu. Kino, z jego ponad 120-letnią dzisiaj tradycją, posiada obecnie własną dostatecznie długą i bogatą historię, aby dostrzec w biegu jego rozwoju fazy i świadectwa cyklicznego występowania idei correspondance des arts.

To samo dotyczy zmieniających się wciąż sposobów jej adaptowania i pojmowania: oświeceniowo-klasycystycznego, romantycznego, apolińskiego, dionizyjskiego, modernistycznego, awangardowego, etc. Niektóre z nich są zbliżone, inne mogą być całkiem przeciwstawne. Gdy dwóch mówi to samo, niekoniecznie chodzi im o to samo. Idea ta co innego znaczy w oświeceniowych poglądach Gottholda Ephraima Lessinga (hołdujący antycznym poglądom na ten temat, klasycyzm spod znaku „ut pictura poesis”), co innego zaś, gdy w fascynującej wizji Cyrku Olimpijskiego jako arcywidowiska - daje o sobie znać w romantycznej praktyce dramatyczno-teatralnej Mickiewicza, Słowackiego i Krasińskiego.

Korespondencja sztuk należy do tych kluczowych zagadnień, które inspirują filmowców praktycznie od momentu, kiedy kino zaczęto traktować jako pełnoprawną sztukę. Najpierw, u swych początków, kinematografia była w najlepszym razie sztuką młodszą („siódmą sztuką” czy „Dziesiątą Muzą”). Nobliwa rodzina sztuk oraz nauk tradycyjnych i wielce szacownych z wyższością, ale i zazdrością spoglądała na sukcesy frywolnej aspirantki. Choć młodziutkiej Filmii przybywało doświadczenia i spektakularnych osiągnięć, to jednak - niezależnie od młodego wieku - ciągle uchodziła za sztukę gorszą. Gorszą, czyli taką, która - ze względu na swoje niskie pochodzenie, „mechaniczność" i uwarunkowania technologiczne - rzekomo nie umywa się nawet do muz tradycyjnych i nigdy nie będzie zdolna im dorównać. Kompleks starszych sióstr jest dla psyché sztuki filmowej rzeczywistością, od presji której - mimo tylu własnych wielkich osiągnięć - nie zdołała się ona uwolnić aż po dzień dzisiejszy.

W materii poruszanych tu spraw stan obecny nie różni się niczym specjalnym od sytuacji sprzed dziesiątków lat. Te same paradoksalne dążenia. $Z$ jednej strony, kino, od kiedy po raz pierwszy zapragnęło być sztuką i spróbowało „wybić się na niepodległość”, konsekwentnie zmierza do tego, by osiągnąć pełną samodzielność i nie zaciągać żadnych kredytów u innych sztuk. Z drugiej, nie potrafi ono żyć pełnią własnego istnienia na sztucznie stworzonym terytorium odcięte od ożywczych wpływów płynących ze strony: literatury, sztuk plastycznych, teatru, tańca czy muzyki.

Marzenie o byciu sztuką syntetyczną bądź sztuką sztuk nie jest w kinie niczym nowym. Eklektyzm ten rodzi jednak uzasadnioną obawę dominacji ze strony sztuk innych, otwierając z kolei drogę idei „Czystego kina”, zdolnego istnieć w sposób absolutnie autonomiczny. Oba dążenia ścierają się i rywalizują z sobą nieustannie. Odwieczny antagonizm. Tak było stulecie temu, w zamierzchłej przeszłości, tak jest również obecnie. $Z$ jednej strony endogenny, z drugiej egzogenny 
charakter pierwiastka artyzmu w filmie. Autonomia versus zależność. Odrębność contra symbioza. Separatyści i integryści - dwa różne stanowiska, dwa sprzeczne poglądy i dwie różne frakcje w spojrzeniu na Dziesiątą Muzę. A wraz z nimi dwie wizje sztuki i twórczości filmowej, którym hołdowali i nadal hołdują zarówno sami filmowcy, jak i teoretycy kina.

„My oczyszczamy sztukę filmową z muzyki, literatury i teatru, które się do niej garną" - deklarował w latach dwudziestych Dziga Wiertow" [1].

„Czy film albo to, co z niego zostało, nie może już istnieć sam, nie może sam poruszać się bez szczudeł literatury i teatru" - wtórował mu blisko trzy dekady później André Bazin[2].

Przytoczone powyżej, modelowe wręcz dla podejścia „separatystycznego", stanowisko Wiertowa, Bazina i innych kategorycznie rozstrzyga, czym powinien być film jako sztuka właściwa. Idea „filmu czystego", to znaczy całkowicie wolnego od wpływu innych sztuk, choć w założeniu bardzo atrakcyjna, nie wyczerpuje jednak rozważanej tu kwestii. Świadczy o tym choćby diametralnie odmienne zdanie Romana Ingardena, który twierdził na ten temat coś wręcz przeciwnego, umieszczając widowisko filmowe na pograniczu wielu sztuk.

„Widowisko filmowe - twierdził Ingarden - jest tworem artystycznym stojącym na pograniczu wielu sztuk, które współdziałając z sobą, splatają się w twory całkiem osobliwe" [3].

Zaliczony przed chwilą, dodajmy całkiem niesłusznie, do obozu „separatystów” André Bazin w cytowanym przed chwilą znakomitym studium pod tytułem O film nieczysty: obrona adaptacji z podziwu godną przenikliwością krok po kroku zweryfikował szereg wcześniejszych uproszczonych poglądów na tę kwestię. Do idei tej powracał w swoich pismach wielokrotnie, a jego spojrzenie na film w kontekście powinowactwa sztuk z biegiem lat dzięki uważnej obserwacji praktyki twórczej kina pogłębiało się i ewoluowało. Bazin nie był przy tym ani stronnikiem awangardystów: malarzy, fotografików, dramaturgów, poetów itp., optujących (cóż za paradoks!) za „czystym kinem”, ani też rzecznikiem praktyków „z branży”, reprezentantów zachowawczego nurtu w przemyśle filmowym.

„Historia filmu, która zaczyna się w początku tego wieku konstatował - jest rezultatem z jednej strony - specyficznej ewolucji tej dyscypliny: a z drugiej - ewolucji innych sztuk i wpływu owych sztuk na film" [4].

W świetle takiego ujęcia, sprzeczność, o której mowa, przestaje być nierozwiązywalnym paradoksem i nabiera cech systemowych.

[1] D. Wiertow, My. Wariant manifestu, przeł. T. Karpowski, w: Człowiek z kamera, Warszawa 1976, s. 18. [2] A. Bazin, O film nieczysty: obrona adaptacji, w: Film i rzeczywistość, wybór tekstów, przekład i posłowie B. Michałek. Warszawa 1963, s. 81.
[3] R. Ingarden, Kilka uwag o sztuce filmowej, w: Studia $z$ estetyki, t. 2, Warszawa 1966, s. 315.

[4] A. Bazin, op. cit., s. 82. 
Systemowość tę rozpoznajemy zarówno w pojedynczych dziełach, jak i w obrębie dialektyki procesu historycznego przemian sztuki filmowej. Idea „czystego kina” okazuje się ideą wprawdzie separatystyczną, ale równie pociągającą i godną uwagi, jak - konkurencyjna względem niej - głęboko zakorzeniona w dziejach sztuki filmowej idea kina jako syntezy sztuk. Kto w tym sporze ma rację? Rzecz w tym, że słuszność na swój sposób mają obie zwalczające się strony. I nie jest to wcale spór pięknoduchów z pragmatykami. Nie sposób w końcu nie zauważyć, że dzieło filmowe tworzy $\mathrm{z}$ reguły nie jeden człowiek, choćby nawet nie wiem jak wszechstronny, lecz wielosobowa ekipa twórców uczestniczących w jego realizacji.

„Można by powiedzieć - pisał wiele lat temu Erwin Panofsky że film powołany do życia wspólnym trudem - przy czym wysiłek wszystkich współpracowników osiąga w dziele ten sam stopień trwałości - jest współczesnym ekwiwalentem średniowiecznej katedry. Rola producenta odpowiada tu mniej więcej roli biskupa czy arcybiskupa, rola reżysera - roli głównego architekta, a scenarzystów porównać można do doradców scholastycznych, którzy ustalają program ikonograficzny dzieła. Co zaś do aktorów, operatora, montażystów, dźwiękowca, charakteryzatora i innych techników - to ich wysiłek porównać można do pracy rzeźbiarzy, witrażystów, brązowników, wykwalifikowanych murarzy i cieśli aż po kamieniarzy i stolarzy: to znaczy tych wszystkich, którzy nadają dziełu jego fizyczny kształt. Jeśli rozmawia się z tymi ludźmi, to każdy z nich powie w całkowicie dobrej wierze, że jego wkład pracy był najważniejszy. Jest to prawdą w tym sensie, że jego praca była niezbędna” [5].

Kapitalne porównanie Erwina Panofsky'ego, łączące dzieło filmowe ze średniowieczną katedrą, należy do natchnionych w swej trafności. Jego autor jednak linijkę dalej sam wydaje się nim zaskoczony do tego stopnia, iż czuje się w obowiązku złożyć autokorektę w osobnym komentarzu, pisząc: „To porównanie wydaje się nam świętokradcze, nie tylko dlatego, że proporcjonalnie istnieje mniej dobrych filmów niż dobrych katedr, ale także dlatego, że kino jest komercjalne" [6].

Jak widać, wielki historyk sztuki, rozpatrując w roku 1947 dzieło sztuki filmowej w analogii do gotyckiej katedry, miał jednak wstydliwe poczucie świętokradztwa wobec ars divina jako intelektualnego sacrum. Popełniał wprawdzie to świętokradztwo całkiem świadomie, lecz mimo osobistej premedytacji wahał się: czy kino to istotnie sztuka, a jeśli tak, to jaka? Nic dziwnego, że na zasadzie swoistego alibi kuchennymi drzwiami w sferę poglądów Panofsky'ego na ten temat wchodzi - sprzeczna z jawnym komercjalizmem przemysłu filmowego - idea czystej sztuki. Dla nas idea ta - poddana koniecznej rewizji i reinterpretacji - może okazać się inspirująca także z innego powodu.

[5] E. Panofsky, Styl i tworzywo w filmie, przeł. B. Michałek, w: Studia z historii sztuki, oprac. J. Białostocki, Warszawa 1971, s. 374. Pierwodruk tego klasycznego dziś studium ukazał się na łamach czasopisma „Critique", 1947, vol. 1, nr 3.

[6] Ibidem. 
Znakomity film Paola i Vittoria Tavianich Good Morning, Babylon (1987) uzmysławia nam z całą oczywistością, że pojęcie udziału sztuki w filmie nie ogranicza się wyłącznie do ram Parnasu. Co więcej, że artystą w filmie jest nie tylko reżyser, kompozytor, scenograf, operator czy aktor, lecz również na przykład murator, kamieniarz, budowniczy filmowych dekoracji. Idea correspondance des arts w odniesieniu do filmu zyskuje tym samym całkiem inny, znacznie szerszy wymiar. Nie chodzi tylko i wyłącznie o okazjonalne przymierza Dziesiątej Muzy z Polihymnią, Terpsychorą czy Melpomeną. Chodzi, z jednej strony, o sztukę w ogóle, z drugiej zaś - o każdą z możliwych dziedzin sztuki stosowanej w szczególności. W przypadku kina tradycyjne wyobrażenie elity muz zamieszkujących Parnas okazuje się zbyt proste i w praktyce przestaje wystarczać.

Aby powstało dzieło sztuki filmowej, konieczne jest nie tylko natchnienie pojedynczego artysty, ale także talent i praktyczne umiejętności wszystkich jego współtwórców. Od nich właśnie zależy ostateczny rezultat. Owszem, film można potraktować jako szczególnego rodzaju syntezę sztuk czy nawet sztukę sztuk. Ale dobrze jest przy tym pamiętać, iż owa synteza sztuk w przypadku filmu oznacza w praktyce nie tylko asystę wianuszka szacownych muz, lecz przede wszystkim precyzyjnie zorganizowany udział rozmaitych (wcale niekoniecznie „pięknych”) kunsztów niezbędnych we wszelkich aspektach jego realizacji.

Nierozstrzygnięta nadal pozostaje kwestia spoiwa łączącego udział poszczególnych sztuk w filmową całość. Poza granicami filmu autonomiczna odrębność literatury, teatru, malarstwa, muzyki nie podlega przecież żadnej wątpliwości. Każda z tych sztuk ma nie tylko własny kod językowy, ale i swoiste tworzywo: literackie, teatralne, malarskie, muzyczne etc. Jak to się zatem dzieje, że właśnie w kinie różne sztuki tańczą wspólnie, tworząc jedność wyższego rzędu? Odpowiedzi na to trudne pytanie dostarcza semiotyka filmu.

W przekazie filmowym spoiwem semantycznym, o które pytamy, staje się każdorazowo język ruchomych obrazów [7]. Tak długo, jak potrafimy czytać film, jesteśmy w stanie odczytać również sens udziału poszczególnych sztuk w jego strukturze. To język ruchomych obrazów jako nadrzędny system modelujący organizuje i jednoczy różnokodowy przekaz. To on wyznacza dla repertuaru wszystkich tych różnorodnych elementów wspólny znakowy mianownik i sprawia, że rozmaite sztuki i kody artystyczne tracą w nim autonomię, zamieniając się w znaki filmowe.

Dotykając tej fascynującej kwestii, warto mieć świadomość, iż - w przypadku filmowej correspondance des arts - pytamy w gruncie rzeczy o morfologiczny aspekt sztuki ruchomych obrazów jako sztuki syntetycznej. Bardziej wnikliwe studia i analizy poszczególnych dzieł

[7] M. Hendrykowski, Język ruchomych obrazów, Poznań 1999. Zob. zwłaszcza rozdziały: „Ekran i kadr”,
"Język ruchomych obrazów jako system modelujący" oraz „Język artystyczny filmu”. 
skłaniają do wniosku, iż koegzystencja różnych sztuk w filmie nie wyklucza się wcale z „czystym kinem”. Współudział różnych dziedzin sztuki osiąga w nich bowiem taki stopień zamierzonej integracji, że zdają się one wychodzić poza siebie i wzajemnie przenikać aż do pełnego stopienia w całość wyższego rzędu. Nie ma już pierwiastka literatury, teatru czy malarstwa. Elementy składowe czerpane z tych sztuk, które uwolniono od macierzystego idiomu, współbrzmią odtąd w granicach struktury dzieła jako jego organiczne cząstki. Właśnie to, czyli ich magiczna transformacja, wprawia nas podczas seansu w stan uniesienia.

Kapitalnego przykładu na jednoczące działanie języka ruchomych obrazów dostarcza muzyka na żywo wykonywana w sali kinowej. Na pozór, wydaje się ona czymś dodanym i „zewnętrznym” wobec strumienia ekranowych fantomów. Ontologicznie biorąc, ze względu na jej realną obecność podczas danego seansu, muzyka ta nie należy przecież bezpośrednio do utworu filmowego. W istocie jednak gra się ją „do filmu” i wykonuje ściśle „pod obraz filmowy”. Tym samym muzyka na żywo zostaje integralnie włączona w strukturę ekranowego widowiska, okazując się jego pełnoprawną (jeszcze jak!) uczestniczką. Dzięki systemowemu pośrednictwu języka ruchomych obrazów wielokodowy przekaz staje się jednolitą zorganizowaną całością. W tym sensie każde dzieło sztuki filmowej można określić jako symfonię obrazów i dźwięków.

Zarówno teoria, jak i praktyka filmu mają od dawna problem z przeestetyzowaniem idei korespondencji sztuk. Sztywno pojmowana, eksponuje ona jedynie kanoniczne pojęcie piękna. W świetle takiego rozumienia, film jako sztuka nowa miałby co najwyżej odtwarzać matryce sztuki teatru, malarstwa, muzyki itp. A przecież właśnie w kinie należne miejsce znajdują dla siebie także najróżniejsze sztuki praktyczne i stosowane. Wszystkie one łączą się w nadrzędną kategorię kunsztu. Ściślej mówiąc: przynależą do mnogiego zbioru przeróżnych kunsztów i umiejętności niezbędnych, aby film mógł uzyskać odpowiedni do zamierzonego materialny kształt.

Dlaczego patrząc na wspaniałą sekwencję balu w ekranizacji Romea i Julii Franka Zeffirellego (1968), dostrzegam w niej współobecność wielu sztuk, ale jako widz nie muszę (a nawet nie powinienem) tego osobno uwzględniać? Łatwo to zrozumieć. Otóż nie dostrzegamy takiej konieczności, bowiem kino w takim jak to wydaniu, wykorzystując i adaptując z myślą o własnych celach sztuki inne, poddaje je serii gruntownych przeobrażeń. Taniec nie jest więc tańcem autonomicznym, lecz tańcem filmowym, to samo z choreografią i muzyką, renesansowa pieśń o miłości nie jest pieśnią, lecz pieśnią w filmie, etc.

W ostatecznym efekcie, to znaczy na ekranie, sztuk innych jest tyle tylko, ile potrzeba filmowi, aby osiągnąć z ich pomocą własny kształt i wyraz. W wyniku „zapożyczeń” z innych sztuk powstaje coś całkiem swoistego i w najwyższym stopniu oryginalnego w swym charakterze. Udział wszystkich tych sztuk (starszych i najstarszych, pięk- 
nych i użytkowych etc.) może być aranżowany w rozmaity sposób i w najróżniejszych proporcjach. Rzecz jednak w tym, iż muszą one zostać zorganizowane w dzieło sztuki filmowej.

Film w takim ujęciu jest więc ewidentnie sztuką złożoną. Podobnie jak tragedia grecka, opera czy taniec, należy on do rodziny sztuk złożonych z wszelkimi konsekwencjami idei correspondance des arts, która leży u podstaw każdego bez wyjątku widowiska filmowego.

Fundamentalną zasadę takiej organizacji w niezrównany sposób wyraził ponad siedemdziesiąt lat temu Rudolf Arnheim w znakomitym studium Nowy Laokoon - sztuki złożone i film. Pisał w nim:

Artyści nie wykazali do tej pory większych uzdolnień lub skłonności do tworzenia dzieł opartych na większej liczbie środków wyrazowych. Oczywiście we wszystkich przytoczonych przez nas przykładach używa się w rzeczywistości więcej niż jednego środka wyrazu, ale z reguły każdą dziedziną sztuki zajmuje się inna osoba i zawsze jedna $\mathrm{z}$ dziedzin ma pierwszeństwo. Dziedzina dominująca rozwija temat w bogatą konstrukcję, którą wspiera w sposób prostszy dziedzina drugoplanowa. Ale mimo to dziedzina drugoplanowa nie może być zlekceważona do tego stopnia, by to, co wyraża, było tanie, ani tak przytłumiona, by przestała w ogóle coś wyrażać. Sztuka dopuszcza hierarchię funkcji, ale nie toleruje ilościowej lub jakościowej atrofii któregokolwiek ze składników, skoro już w dane dzieło został włączony [8].

Konkurencyjny charakter dwóch lub więcej dziedzin sztuki uczestniczących w widowisku filmowym nie jest więc czymś, co każdorazowo zagraża kinu jako sztuce ruchomego obrazu nieuchronną dezintegracją. Na ekranie liczy się bowiem ostatecznie nie to, co je dzieli, lecz mistrzowska aranżacja i orkiestracja, czyli wypracowany przez zdolnego reżysera maksymalnie umiejętny sposób zorganizowania udziału każdej z nich w przekaz oparty na współdziałaniu.

„Muzy nie rozmawiają, ale mogą z sobą zatańczyć” - powiedział przed laty Jean Renoir.

Pora przedstawić ostateczną konkluzję niniejszych rozważań.

Studiując i odkrywając w widowisku filmowym ideę correspondance des arts, a wraz z nią najróżniejsze sposoby łączenia się i integrowania rozmaitych sztuk, dotykamy za każdym razem dwóch istotnych rzeczy. W centrum naszej uwagi znajduje się nie jakaś jedna izolowana dziedzina sztuki wpisana w drugą, lecz dzieło artystyczne jako całość.

Myślenie o korespondencji sztuk - zarówno w wymiarze teoretycznym, jak i praktycznym - nie sprowadza się w filmie do inwentaryzacji, ani do statycznego sumowania pewnej liczby zaangażowanych, uczestniczących w nim dziedzin sztuki. Liczy się przede wszystkim dynamika powołanego do życia dzieła filmowego i jego głębszy artystyczny sens. To w nim każdorazowo odzwierciedla się, fortunny

[8] R. Arnhem, Film jako sztuka, przeł. W. Werten-

stein, Warszawa 1961, s. 171. 
lub niefortunny, udział sztuk innych. Wszystko jedno, czy uchodzą one za „sztuki piękne”, czy też piękno widowiska filmowego wytwarzają i wspomagają.

Myślenie takie, jak najdalsze od „wpływologii”, jest ściśle związane nie ze szkodliwą dla filmu supremacją przykładowo literatury, teatru czy malarstwa, lecz z o wiele bardziej ogólną ideą utworu artystycznego jako niepowtarzalnie zorganizowanej całości. Nie dzieli ono sztuk, nie buduje murów, ani nie wyznacza między nimi granic, a przeciwnie, pomaga je łączyć i jednoczyć w naszej świadomości.

Wielość sztuk i przeróżnych kunsztów obecnych w filmie ewokuje intrygującą myśl o możliwym ich zjednoczeniu. W dziedzinie tej zajmowanie się ideą korespondencji sztuk ma również inny, znacznie szerszy wymiar. W dobie ścisłej specjalizacji coraz bardziej rozdrobnionych dyscyplin artystycznych idea korespondencji sztuk, w odniesieniu do filmu i nie tylko, przypomina nam o uniwersalności sztuki jako takiej. Żadne dzieło filmowe, nawet tak znakomite jak Obywatel Kane, Osiem i pół czy Fanny i Alexander, nie jest jej idealnym urzeczywistnieniem. W swoich największych dokonaniach przypomina ono jednak, że urzeczywistnienie owej idei jest możliwe do osiągnięcia i że artysta filmowy (od twórczego producenta i reżysera począwszy, a na oświetlaczu, cieśli, kamieniarzu i muratorze z filmu braci Tavianich skończywszy) potrafi niekiedy zbliżyć się do niego jak nikt inny. 